\title{
Can Greater Openness and Deeper Financial Development Drag ASEAN-5 into Another Series of Economic Crises?
}

\author{
Samsudin $\operatorname{Hazman}^{1}$ \\ ${ }^{1}$ Faculty of Management and Economics, University Malaysia Terengganu, Malaysia \\ Correspondence: Samsudin Hazman, Faculty of Management and Economics, University Malaysia Terengganu, \\ Malaysia. Tel: 60-96-68-3868. E-mail: hazman.s@umt.edu.my
}

$\begin{array}{lr}\text { Received: March 22, } 2016 & \text { Accepted: June 1, } 2016 \quad \text { Online Published: July 7, } 2016 \\ \text { doi:10.5539/ass.v12n8p125 } & \text { URL: http://dx.doi.org/10.5539/ass.v12n8p125 }\end{array}$

\begin{abstract}
In the event of economic crises, it is observed that economic volatility becomes more severe. Therefore, the aim of this study is to examine the impact of greater openness and deeper financial sector development in influencing the level of economic volatility which could trigger economic crises in both long-and short-run periods in the case of ASEAN-5 countries, namely Indonesia, Malaysia, Philippines, Singapore and Thailand. Given that more attention is needed to address the issue, the Pooled Mean Group (PMG) estimations developed by Pesaran et al. (1999) and data ranging from 1980 to 2014 were employed to address the issue. With the ability to estimate short-run coefficients at each country level and its speed of adjustment, this study further fills the knowledge gap. Based on the analysis, it is found that greater trade and financial openness may further relax economic volatility in the long-run, suggesting greater international risk sharing which soothes consumption shocks. In terms of the effect of financial development towards economic volatility, it is found that only deeper banking sector development may reduce economic volatility in the long-run, but the same may not apply in the case of greater stock market development. Particularly, it is suggested that it is in the nature of developments in the banking sector to likely provide longer financing options and greater banker capabilities in detecting riskier investments, thus giving a favourable impact on economic volatility. It is a contrast with the stock market sector where it is more likely to be more susceptible towards large and sudden capital outflows. Its tendency to provide capital towards riskier investments may worsen volatility in the longer term. Nevertheless, in the short-run, the effects of greater openness and financial development is not as obvious as in the long-run; financial openness and greater stock market sector development may significantly relax economic volatility. As suggested by the speed of adjustment, the equilibrium from short-run to long-run is corrected by $1.71 \%$ and $2.33 \%$ in a year. Cumulatively, it can be said that there is no evidence that greater openness and deeper financial development may drag ASEAN-5 into another series of crises except in the case of stock market sector development. Therefore, the source of instability in the region is likely to be driven from greater stock market sector development rather than greater openness and banking sector development.
\end{abstract}

Keywords: business cycle, financial development, financial openness, trade openness

\section{Introduction}

The rapid economic expansion and several economic crises of Asian countries, especially in the ASEAN-5, in recent decades have made the South East Asian region in the centre of debate over the last three decades (Note 1) (Note 2). Even though the region has experienced a remarkable structural change and considerable enhancement in the standard of living especially from the 1970s until the mid-1990s (Asian Development Bank, 1997) which once applauded by the World Bank and the IMF as part of the "Asian economic miracle" (World Bank, 1993, p. 1), these economies has also suffered from series of economic crises. Particularly, these economies have endured the 1973 oil price crisis, early 1980's global economic slowdown, the 1985 Singapore financial collapse due to falling demand in Singapore's goods and services as a result of the slump of the worldwide petroleum and marine related sectors which consequently affected the whole region, the most notably 1997 economic crises, the early 2000 global economic slowdown as a result of 1997 crisis, affected from the U.S sub-prime crisis which emerged in 2008 and the recent ongoing effect of economic contagion which spread fast from the EU as well as the effect of China economic slumped. This shows that the ASEAN-5 has experienced more crises than booming. In light of these economic occurrences, however the source of the crises remained debatable. 
Nonetheless, as past experience shown, the series of crises has become more persistent in recent decades, especially after economic opening and financial reform (Hnatkovska \& Loayza, 2003). It was notably that ASEAN-5 has taken massive steps of liberalisation since 1970 especially after the establishment of ASEAN in order to realize economic transformation from agriculture towards industrialization based economy which consequently turns these economies into among the leading exporters of world industrial goods (Note 3). Financial liberalisation policies were also introduced in order to support the economic transition where the injection of investment and financial assistance to fund the transition was barely needed.

The transition also has urged the need for financial sector reform to support the burgeoning industrialisation. The capability of financial sector need to match the escalating demand from the real sectors hence the development of financial sector through several financial reform is also prioritised. However, to the extent those financial reform and greater openness has created a sustainable economic development in ASEAN-5 are questionable. As highlighted previously, economic crises has become more severe in recent decades, especially after economic opening and financial reform (Hnatkovska \& Loayza, 2003). And interestingly, in the event of economic crises, economic volatility has become more severe. Figure 1, further supports the arguments where economic volatility has become more persistent in ASEAN-5 countries recently.

vol

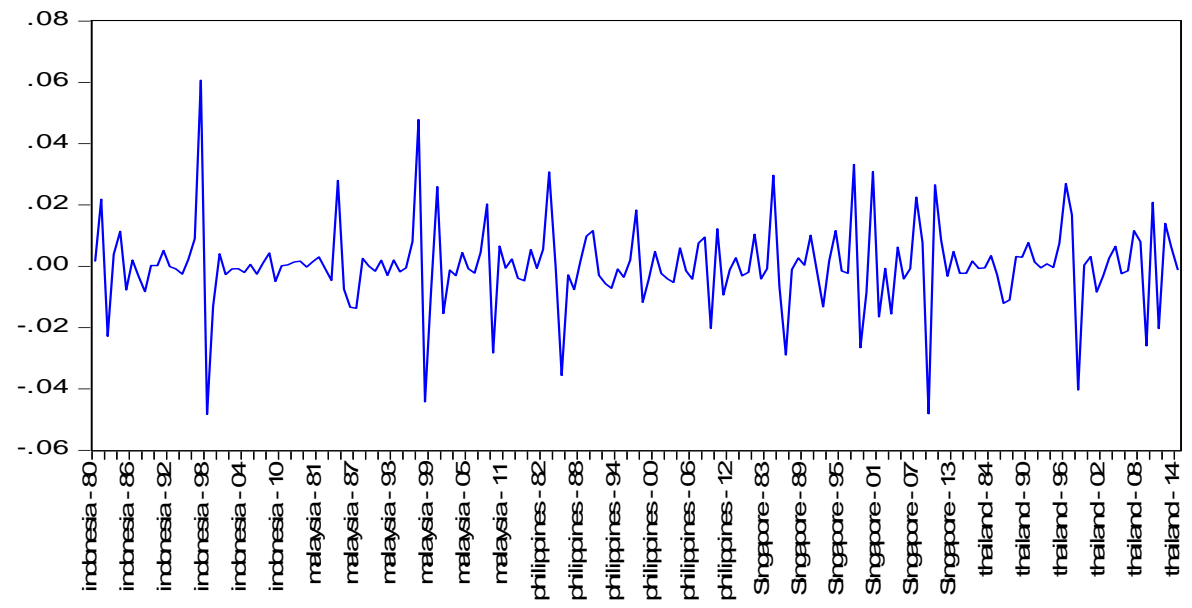

Figure 1. The cyclical component of GDP of ASEAN-5 which is derived through BP (Band-Pass) filtering method

This sparks the concern whether greater openness (Note 4) to the world market and deeper financial development (Note 5) leads to more volatile state of economy. Or it has become the engine for sustainable economic growth especially in case of ASEAN-5. It is often argued and observed that even if openness and financial development may bolster economic development, openness is more often deemed to be the source of instability due to vulnerability to external shocks as has been witnessed nowadays. This is also not limited to the role of financial sector development in preserving economic stability which has become increasingly dubious especially after the US sub-prime and EU economic crises. It is argued that a well-developed financial system may not always lead to lower economic volatility as an increase in financial development is usually followed with the creation of new financial instruments which are usually risk indivisible. The inability to diversify risk may intensify the risk of triggering volatility which may lead to economic crises. If a country with a well-developed financial system such as the US and EU may also suffer from the reverse effect of financial development, then emerging economies and countries with intermediate levels of financial development may even be at risk (Aghion, 2004).

Interestingly, despite the conundrum, it has had little attention in the literature and there are still questions to be answered. Most of past studies concentrated on the effect of financial development and openness in promoting sustainable economic development, while very little attention is given in understanding its implications in triggering economic crises. Past literature also offers very limited information that looks at which indicator of financial development and openness would have a more stabilizing or destabilizing effect. Specifically, none of the studies has compared the effect of banking sector and financial market sector development/ trade and financial openness towards economic volatility; especially with regards to ASEAN-5 countries.

With the current state of literature and economic dilemma, this study was motivated to further investigate the 
issues. The arrangement of this paper will follow with the discussions on the selected past literature, then proceeded to the model development and econometrics specifications, data descriptions and sources, the interpretation of econometrics analysis and lastly, concluded with some policy recommendation.

\section{Selected Literature}

As highlighted in the previous section, the available literature pertaining to the effect of financial development and openness in affecting economic volatility is very limited (Note 6). Among the first to discuss the effect of trade openness on economic volatility is such as Razin and Rose (1992) who argued that an increase in trade with increased specialization of intra industry as a result of greater trade openness would lead towards a decline in output volatility due to the greater volume of intermediate input trade for a group of 138 countries during 1950 to 1988. This shows that, trade openness may further improve resource allocation, lower consumers' prices and lead to more efficient production, thus reducing volatility. It may also further encourage technological transfer, which may result in productivity improvements and promise a more sustainable economic development which could mean a reduced impact on volatility. It is therefore not surprising that international organizations and almost every country advocate policy reforms centred on trade liberalisation. Samsudin (2013) also point out that an increase in trade openness may reduce the chances of inflationary shocks which could trigger volatility. This is because trade openness may reduce excess demand for goods and services and therefore avoid undesired price shocks. Such a situation may also have a smoothing effect on private consumption which may relax economic volatility. The author also assert that an increase in competition due to greater trade openness may also increase industry efficiency in production, and higher levels of efficiency could lead to better resource allocation and economies of scale. This could prevent, or at least minimize, any risks related to undesired shocks. The finding was based on dynamic time series analysis for five ASEAN countries.

On the other hand, greater financial openness also could lead to better risk sharing and a well-diversified investment portfolio. These attributes could be vital in reducing the impact of economic shocks. In other words, extracting the capital control will permit both domestic and foreign investors to have a more diversified portfolio and improve risk sharing which may lower economic volatility. This is in line with Chinn and Ito (2006) who study a group of 108 countries, including 21 industrialized countries and 31 emerging market countries, and Bekaert et al. (2006) with a group of 95 countries in which 50 countries that were mainly industrialized and some emerging economies with an active stock market, and 30 countries with emerging equity markets in a cross-country analysis. Beck et al. (2004) also added that for industrial sectors that strongly depend on external financing may constitute a comparative advantage for them which may ease volatility arise from consumption shocks for 36 industries and 56 countries from 1980 to 1989 provided by cross-country analysis. Besides, McKinnon (1973) and Shaw (1973) also argue that the basic idea underlying openness is that capital openness may push the real interest rate to its competitive market equilibrium as financial liberalisation may make financial repression in protected financial markets smooth which, in turn, could invite more investment and shorten the cycle of volatility.

Kose et al. (2006) who examined a panel data for a sample of 85 countries of which 21 were industrial countries and the other 64 were a group of developing countries also argued that deeper financial development could further reduce volatility by providing access to capital which may assist in diversifying the production base and hence reduce the effect of industrial specific shocks. Besides that, Silva (2002) also pointed out that the financial sector could reduce risk and volatility through its role in facilitating diversification and reducing asymmetric information through the increased capability of financial institutions to identify projects with high probability of failure in a study based on a mixed sample of 40 developed and developing economies with data availability from 1960 until 1997, and by utilizing the generalized method of moments (GMM) framework based on a cross-sectional dataset. This effect is also known as the double welfare improvement effect, which is useful for easing economic problems, especially in developing countries. Kim et al. (2009) also add that better financial institutions and markets might also provide information concerning profitable ventures, diversify risks and facilitate resource mobilization (Note 7). To a certain extent, these effects of financial development may reduce economic volatility due to increased confidence and certainties on return and, thus, increase the level of investment and promote economic growth (Pindyck, 1991). Therefore, a well-developed financial system assists in improving the capital structure and efficiency of resource allocation, thereby promoting long-run economic growth (Kim et al., 2009) and reducing economic volatility (Ahmed \& Suardi, 2009).

Despite the findings of a smoothing effect flowing from financial development and openness towards economic volatility which may instil a prominent sustainable economic growth, there are also other studies who suggest the opposite direction. For instance, Razin et. al. (2003) explained that trade openness is likely to offer abundance of imported goods and services in an economy and this may risk losing domestic producers if they fail to keep up 
with the standards and expectations. If that situation occurs, unemployment will rise and disrupt the level of private consumption. This may lead to a widened trade deficit which eventually may trigger volatility. The finding is based on a group of developed and developing economies. Additionally, Kalemli Ozcan et al. (2003) analysed a cross regression for 15 most specialized regions also argued that trade openness may encourage specialization of production based on comparative advantage assumptions and make an economy more vulnerable to industry specific shocks if they fail to diversify. This shows that greater openness to world goods markets may bolster domestic economic fluctuations because of reliance on the international environment, such as exchange rates and international price levels (Arora \& Vamvakidis, 2004; Blankenau et al., 2001; Rodrik, 1998) and, hence, lead to sensitivity to external shocks.

Aside of that, greater financial openness may also potentially harm economic volatility. This is because liberalisation could increase the chances of higher external shocks due to removal of capital controls, and greater economic integration could lead to economic contagion (Schmukler, 2004a, 2004b). Some researchers even argue that an open economy will make any country more crisis prone, as they are more vulnerable to volatility and instability as capital flows are cyclical in nature, and this might explains the increasing recurrence of financial crises which weaken economic swing especially for developing economies (Stiglitz, 2000). Interestingly the assertion was made based on developing South East Asia economies. In addition, according to Ang and Mckibbin (2007), liberalisation may increase economic volatility in the financial system and, hence, trigger a financial crisis if carried out improperly. Aghion et al. (2004) highlight that liberalisation might destabilize the economy as it will speed up the chronic phase of growth with inflows of capital which, subsequently, is followed by economic failure and capital flight especially for economies that are at the intermediate level of financial development and going through the phases of development. This also shows that, financial market liberalisation may open new channels for the entry of foreign capital which consequently leads to appreciating real exchange rates and a rapid expansion of bank lending and, thus, increasing the chances of economic overheating and vulnerability to a turnaround in capital flows. This argument is supported by Buch et al. (2005) who contend that the link between financial openness and volatility has not been stable over time for 24 OECD countries from 1960 until 2000.

Financial development also may not necessarily lead to lowering economic volatility. It is pointed out that financial development will normally be followed by the creation of a more sophisticated financial system and instruments, such as forward trading, which could then open up more room for speculative activities and thus trigger volatility. As history has shown, the early 1990s financial crisis in Europe and the mid-1990s Asian financial crisis were driven by uncontrolled speculation activities. The source of instability also could derive from too many options on financial instruments, which could increase the asymmetric information problem and lead to adverse selection and moral hazard. Even a supposed increase in financial development should decrease the asymmetric problem, but still the possibilities of failure to detect profitable investment could occur when abundance of sophisticated financial instruments and systems are introduced. With investors having problems in detecting profitable investment and incurring losses in investment, the problematic situation could then persuade them to pull out their investment which could then trigger economic volatility. In this sense an increase in financial development could lead to a more volatile economy due to adverse selection and moral hazards. In this case, adverse selection and moral hazards are caused by an increase in the asymmetric problem arise from the abundance of financial instruments and sophisticated financial systems which sometimes are risk indivisible. As stressed by Acemoglu and Zilibotti (1997), the interaction of investment indivisibility and the consequences of inability to diversify risk further intensifies economic volatility. On the other hand, monetary shocks could also increase the chance of economic volatility, particularly when monetary policies often change. This argument is supported by Beck et al. (2004), while others, such as Kiyotaki and Moore (1997), point out that the imperfections of the capital market could magnify the effects of momentary productivity shocks and make them more persistent.

After a brief review of the literature it was found that the findings about the effect of financial development and openness for economic volatility are still vague and mixed; thus motivating this study to further extends the work already done. It is also observed that the focus area for the present study (ASEAN-5 countries) has received less attention even though the region has undergone several financial reforms, and has experienced a serious liberalisation process with meaningful economic arrangements among its counterparts. ASEAN's contribution to world economic growth is apparent, while its popularity as a destination for world investments is ever increasing. Therefore, this study fills a gap by focusing on the effect of openness and financial development towards economic volatility based on ASEAN-5 countries, which has been neglected in past studies. Additionally, most of past studies examined the impact of financial development and openness for economic volatility in a static 
model while very few analyse the dynamism on the said issue. In other words, in dynamic model the short-run implications can be further detected. Nevertheless, it is noted that the past studies matter to its own arguments and objectives, and therefore the present study tempt to fill the remaining loopholes.

\section{Model Specification and the Method of Estimations}

As explained earlier, financial development and openness are somehow interrelated in explaining economic volatility which reflect the event of economic crises. Therefore, the economical function of the determinants of economic volatility can be written as (1).

$$
\mathrm{Vol}=\{F D, O P\}
$$

In function (1) the term $\mathrm{Vol}$ refers to economic volatility which represents economic crises, $F D$ refers to financial development which can be divided into two segments; banking and stock market sector development. Meanwhile, $O P$ is openness which can be further broken down into financial and trade openness. Therefore, functions (1) can be further written as equation (2).

$$
\operatorname{Vol}_{i t}=\alpha+\beta_{1} \text { Bank }_{i t}+\beta_{2} \text { Mrkt }_{i t}+\beta_{3} \mathrm{FO}_{i t}+\beta_{4} T O_{i t}+\varepsilon_{i t}
$$

Where $\alpha$ and $\beta$ are the parameters to be estimated while $\varepsilon$ is the error term referring to $i^{\text {th }}$ country at time $t$. In equation (2), $F D$ is divided into banking and stock market sector development denoted by Bank and Mrkt respectively. Meanwhile, $O P$ is divided into financial and trade openness which is represented by $F O$ and $T O$ as elucidated. In equation (2), the entire variables in the model are transformed into a logarithm form. By doing so it may avoid, or at least reduce other problems such as heteroscedasticity and widely varying data which lead to data precision error measurements (Note 8). Other than its main purposes in reducing the biasness of the data and reducing other errors and problems, one of the biggest advantages of turning the data into logarithms is linearisation of the model, where it may reduce the chances of regression equation specification error (Note 9). Also, by taking a logarithm form the estimated coefficients of $\alpha$ and $\beta$ in equation (2) will be interpreted as elasticities.

With having the model specifications of equation (2) set up and taken the logarithm form, the long-run co-integration model is now ready to be tested. As mentioned earlier, aside of detecting the long-run relationship between financial development and openness for economic volatility, this study also attempts to extract the possibility of the non-causal relationship among these variables in the short-run.

This can be done by introducing the Autoregressive Distributed Lag (ARDL) model at each country level. For this purpose, the entire sample countries are then pooled in a panel and further test for cross-equation restriction to detect for common long-run relationship through the Pooled Mean Group (PMG) estimator developed by Pesaran et al. (1999). Under this technique, the respective long-run and short-run associations are estimated by pooling both time-series and cross sectional effects in a panel rather than isolating the trend effects through averaging the data for each country. The advantages of this averaging may lead to the loss of useful information in estimating a more flexible model which permits for heterogeneity parameter across countries. Averaging also may not reveal the dynamism of the relationship between financial development and openness on economic volatility, especially in the presence of reverse effects at various time frequencies (Note 10).

Furthermore, the PMG estimator will also be consistent even if there is a mixed level of stationarity of $I(1)$ or $I(0)$ among the variables. Therefore, unit root testing prior to co-integration testing is not required (Note 11). Another advantage of this method is that the estimations may also allow for dynamism in the analysis which will be an added advantage, especially in understanding the lagging effect of the variables. This is an important aspect of economy where some of the policies or shocks may not instantly affect the economy but take some time before they take effect. As suggested by Arestis et al. (2002), financial policies especially concerning the financial openness, may usually demonstrate further instantaneous long and short-run implications. Therefore, the method may allow for short-run causality estimation where it has received less attention in the literature. In addition, the suggested method may also allow for homogeneity restrictions only in the long-run parameters across country, while in the short-run the error variances are permitted to vary across countries. Besides that, unlike in the other panel estimation, the PMG may also estimate the speed of adjustments where it indicates the rate of adjustment to restore equilibrium due to economic shocks.

With those underlines advantages, this study utilised the PMG estimator developed by Pesaran et al. (1999) in order to understand the effect of financial development and openness on economic volatility in the case of ASEAN-5 countries. Way to precede, equation (1) is nested in an ARDL specification where it may permit for rich dynamics in the manner that economic volatility reacts to the change in financial development and openness. Therefore, the ARDL model with lags order of $p$ and $q$ where the endogenous and exogenous variables enter the 
right-hand side of the model, can be written as per equation (3).

$$
y_{i t}=\mu_{i}+\sum_{j=1}^{p} \lambda_{i j} y_{i t-j}+\sum_{j=0}^{q} \delta_{i j}^{\prime} x_{i t-j}+\varepsilon_{i t}
$$

In equation (3), it refers to country $i$ at time $t$ (measured annually), $j$ is the lag value, $y$ is the interested endogenous variable of economic volatility which represents economic crises, $x$ is the exogenous variables of financial development and openness, $\mu$ is the fixed effects, $\lambda$ and $\delta$ is the estimated parameter, and $\varepsilon$ is the error term. Re-parameterisation of equation (3) is written as in equation (4).

$$
\Delta y_{i t}=\mu_{i}+\phi_{i} y_{i t-1}+\beta_{i}^{\prime} x_{i t}+\sum_{j=1}^{p-1} \lambda_{i j}^{*} \Delta y_{i t-j}+\sum_{j=0}^{q-1} \delta_{i j}^{*^{\prime}} \Delta x_{i t-j}+\varepsilon_{i t}
$$

Where,

$$
\begin{gathered}
\phi_{i}=-\left(1-\sum_{j=1}^{p} \lambda_{i j}\right), \beta_{i}=\sum_{j=0}^{q} \delta_{i j}, \\
\lambda_{i j}^{*}=-\sum_{m=j+1}^{p} \lambda_{i m}, j=1,2, \ldots, p-1 \text { and } \\
\delta_{i j}^{*}=-\sum_{m=j+1}^{q} \delta_{i m}, j=1,2, \ldots, q-1 .
\end{gathered}
$$

Then, the variables are further grouped in a level which allows equation (4) to be rewritten as an error correction model as in equation (5).

$$
\Delta y_{i t}=\mu_{i}+\phi_{i}\left(y_{i t-1}-\theta_{i}^{\prime} x_{i t}\right)+\sum_{j=1}^{p-1} \lambda_{i j}^{*} \Delta y_{i t-j}+\sum_{j=0}^{q-1} \delta_{i j}^{* \prime} \Delta x_{i t-j}+\varepsilon_{i t}
$$

Where, $\theta_{i}=-\left(\beta_{i} / \phi_{i}\right)$ indicates the long-run relationship between $y_{i t}$ and $x_{i t}$, while $\lambda_{i j}^{*}$ and $\delta_{i j}^{*^{\prime}}$ are the short-run causality coefficients of economic volatility based on its past values and other determinants $\left(x_{i t}\right)$ respectively. $\phi_{i}$ represent the coefficients of Error Correction Term (ECT) which determines the rate of adjustment for $y_{i t}$ to restore to its long-run equilibrium when there is a shock in $x_{i t}$. For there is a long-run relationship between $y_{i t}$ and $x_{i t}$, the value of $\phi_{i}$ should be less than zero $\left(\phi_{i}<0\right)$. In other words, the existence of long-run relationship or cointegration between financial development and openness on economic volatility is indicated by the negative and significant value of $\phi_{i}$. Otherwise, there is no long-run cointegration between $y_{i t}$ and $x_{i t}$.

With the equation and regression model specified, the effect of financial development and openness on economic volatility which represents economic crises can be further analysed. The next section discusses the source of data used in this study and descriptions on each variable.

\section{Data Descriptions and Sources}

In conducting the analysis, an annual panel dataset of ASEAN-5 countries for the period covering from 1980 up to 2014 were employed. All of the data were obtained through the World Development Indicator (WDI) online database published by the World Bank. Except for the financial openness indicator, the data was compiled by Lane and Milesi Ferretti (2006) (Note 12), and both banking and stock market development indicators were obtained from Financial Structure Database which was first compiled by Beck et al. (2000).

After determining the source of data, the next crucial step would be to determine which data to be selected as the best proxy for each variable based on its definition. As stated earlier, economic volatility has become more severe in the event of economic crises, and therefore a cyclical component of GDP is used as a proxy for economic volatility. By definition, volatility refers to the deviation of the particular time series data from its mean. Based on the definition, taking the cyclical component of GDP may well suit the need of the study. To date, there is no specific data to reflect on volatility directly, however has to be derived explicitly. In order to derive the data, Band-Pass (BP) filtering method is utilised rather than linear detrending, first differencing and Hodrik-Prescott (HP) filtering method. Particularly, the linear detrending tends to create spurious cycles when the series of data are not "trend stationary". On the other hand, the first differencing also may suffer from variables timing relationship bias and tends to overweight the short-run fluctuations. The HP filter is deemed to be better from the former and has been widely utilised in the studies dated back to 1980s and early 1990s. Nevertheless, the HP filter still possesses some weaknesses where it tends to overweight high-frequency fluctuations and the data cyclical component demonstrates unusual behaviour approaching towards the end of the sample. Furthermore, when dealing with annual data series, the HP filters has a very weak performance, hence it is not preferable in this study (Note 13). Unlike the BP filter, the method is specially designed to cope with annual data series, and remove out pre-specified range frequencies in the data components (Baxter \& King, 1999). According to the author, the BP filter addresses important aspects of optimal filter (Note 14). Therefore, BP filtering method is utilised in deriving the cyclical components of GDP to reflect economic volatility which represents economic crises.

As for financial development indicator, two proxies were utilised in this study, namely the banking sector 
development and stock market sector development (Note 15). It is argued that the bank-based measurements are often related to the long-term financial development. This is because banks are able to offer long-term financial assistance compared to market-based, which is often associated with short-term capital especially for firms being primarily concerned with immediate performance (Ang \& McKibbin, 2007). Given that there are very limited studies that look at which indicator of financial development would have a more destabilizing effect, these two variables should be distinguished as it is expected that these two variables may implicate different effects on economic volatility (Note 16).

For the purpose of this study, domestic credit to private sector normalized by GDP was used to proxy for the banking sector development. There are several factors why this variable is employed, such as having a better grounded theory, data availability and it is technically sound (Note 17). Another indicator such as M2 is deemed to be a bit 'noisy' because it may contain foreign capital, admit double counting, and overestimate financial development. Besides, other variables, such as domestic total bank assets may not be available for some countries and hence may not be suitable.

For the stock market sector development, stock market capitalisation for GDP was employed as a proxy. It is deemed that stock market capitalisation may best explain stock market development, as it may depict the size of the financial market rather than its activeness and well suit the need of the study. In other words, stock market capitalisation may represent stock market development in terms of its leverage compared to the other measurements and provide a better reflection of stock market development. Compared to the other measurements such as stock market turnover ratio and total value stock traded, both proxies may best depict stock market activeness and may not reflect the ability of capital accumulation which may be inadequate to explain stock market development (Note 18).

For instance, openness is further divided into two segments; financial openness and trade openness. By definition, openness is defined by the degree of compromise on transparency, unrestricted access and collaborative management. Therefore, as pointed out by Schmukler (2004a), "Financial openness can be defined as the integration of a country's local financial system with international financial markets and institutions". As for trade openness, it is best defined as an outflow and inflow in terms of goods and services for a given country.

Based on the definition, financial openness is proxied by the volume of a country's foreign assets and liabilities as a percentage of GDP, or also known as a de facto financial openness indicator. Because the nature of the data that tends to depict the outcome of any policies relating to financial openness, this variable may reflect the true level of financial openness (Note 19). Moreover, the data may reflect a given country's history of financial openness and account for policy enforcement, which the de jure measurements of financial openness fail to demonstrate (Note 20). The de jure measurement of financial openness is the alternative measurement for financial openness and depicts financial openness from a policy point of view without accounting for the outcome. Due to the need of this study to understand the effect of the outcome of financial openness on financial development and economic volatility, the de facto financial openness was found well suited to the study. Given some doubt about the data reliability of the de jure financial openness, the de facto measurement of financial openness seems superior (Note 21) (Note 22). Furthermore, it is also argued that the de facto measurements might be more relevant for a pure test of financial openness hypothesis, where the de facto seems to reflect the true level of openness or outcome based measurements. Whereas, de jure measurements of openness may be closely related to the policy based financial openness measurements. Based on this argument, it seems that de facto was most suitable for this study as this study investigated the impact of financial openness in terms of capital flows rather than the impact of financial openness policy.

On the other hand, trade openness is measured by the ratio of total trade to GDP and this was used as the proxy for trade openness. By taking this approach in deriving the trade openness data, it is believed that it may reflect the history and outcome of trade openness experienced by a given country and be parallel with the nature of $d e$ facto financial openness data. The measurement of trade openness is apparently less complicated and straightforward compared to the other variables measurements. These methods of measurements have been used extensively in the literature.

Having all of the data sources and description of each variable specified, the regression analysis on the issue is further conducted and presented in next section.

\section{The Findings}

As specified earlier, equation (2) is analysed by utilising the PMG approach proposed by Pesaran et al. (1999). Since the method is equipped with the ability to deal with mixed stationarity variables, the test for stationarity is no longer essential. Therefore, the long-run cointegration analysis can be done straightforward. However, it is 
beneficial to undertake some descriptive statistics and correlations analysis on the involved variables in order to understand the underlying properties of each data. Moreover, it is important to undertake these preliminary tests as it is believed that the correlation analysis can extract from all the possibility of scaling problems, especially for the short time series data (Neyapti, 2001). The results of the descriptive statistics and rank correlation test are presented in Table 1 which provides the summary of the analyses.

Table 1. Descriptive statistics and rank correlation matrix

\begin{tabular}{cccccc}
\hline & Volatility & Bank & Stock Market & Financial Openness & Trade Openness \\
\hline \multicolumn{5}{c}{ I- Summary statistics } \\
Mean & 0.0002 & 4.0783 & 3.6299 & 0.4109 & 30.1197 \\
Maximum & 0.0607 & 5.1103 & 6.4306 & 2.5189 & 31.9227 \\
Minimum & -0.0483 & 2.1961 & -2.7562 & -1.1199 & 28.4475 \\
Std. Dev. & 0.0140 & 0.6834 & 1.7909 & 0.8058 & 0.8739 \\
Observations & 175 & 175 & 175 & 175 & 175 \\
\hline Volatility & 1 & 0.0284 & 0.05933 & -0.0587 & 0.0366 \\
Bank & & 1 & 0.6817 & 0.5355 & 0.5897 \\
Stock Market & & & 1 & 0.6782 & 0.6382 \\
Financial Openness & & & 1 & 0.7454 \\
Trade Openness & & & & 1 \\
\hline
\end{tabular}

As indicated in Table 1 Section I, there was no scaling problem and no further modifications to the data were required. The standard deviations of the data are also relatively small in all cases which indicate that the data is spread over a smaller range. In Section II, the cross-correlation among the regressors is also relatively small, which indicates that there is unlikely for multicollinearity. Particularly, none of the regressors exceed $90 \%$ correlation score. On the other hand, the rank correlation matrix also indicates that all of the variables are positively correlated with economic volatility, except for financial openness. Furthermore, the first impression indicates that all of these variables may magnify economic volatility which induces economic crises, except for financial openness which smoothens volatility. Nevertheless, this is not conclusive and further analysis is needed. The next step forward is to conduct a cointegration test based on the PMG approach developed by Pesaran et al. (1999) to provide more conclusive findings. Table 2 summarises the findings.

Table 2. Panel cointegration estimation

\begin{tabular}{|c|c|c|c|c|c|}
\hline & Long-run coefficient & Short-run coefficient & Adjustment coefficient & Constant & $\begin{array}{l}\text { Sample size } \\
\qquad(\mathrm{N} \times \mathrm{T})\end{array}$ \\
\hline \multicolumn{6}{|c|}{ I - Constant (Level) $[\mathrm{AIC}-3,3,3,3,3]$ Maximum lag length set $=4$} \\
\hline \multirow{2}{*}{ Bank } & $-0.0102 * * *$ & 0.0269 & & & \multirow{8}{*}{160} \\
\hline & $(0.0029)$ & $(0.0199)$ & & & \\
\hline \multirow{2}{*}{ Stock } & $0.0065^{* * *}$ & $-0.0226^{* *}$ & & & \\
\hline & $(0.0013)$ & $(0.0106)$ & $-1.7147 * *$ & $0.0657 * *$ & \\
\hline \multirow{2}{*}{ Fin Op } & $-0.0049^{*}$ & $-0.0198 * *$ & $(0.6887)$ & $(0.0282)$ & \\
\hline & $(0.0025)$ & $(0.0095)$ & & & \\
\hline \multirow{2}{*}{ Trd Op } & -0.0006 & 0.0153 & & & \\
\hline & $(0.0011)$ & $(0.7984)$ & & & \\
\hline
\end{tabular}




\begin{tabular}{|c|c|c|c|c|c|}
\hline \multicolumn{6}{|c|}{ II - Linear Trend $[\mathrm{AIC}-4,4,4,4,4]$ Maximum lag length set $=4$} \\
\hline \multirow{2}{*}{ Bank } & $-0.0316^{* * *}$ & 0.0535 & & & \multirow{8}{*}{155} \\
\hline & $(0.0019)$ & $(0.0359)$ & & & \\
\hline \multirow{2}{*}{ Stock } & $0.0192 * * *$ & $-0.0469 *$ & & & \\
\hline & $(0.0017)$ & $(0.0249)$ & $-2.3376^{*}$ & $0.4144 * *$ & \\
\hline \multirow{2}{*}{ Fin Op } & $-0.0038 * *$ & -0.0222 & (1.1792) & $(2.0531)$ & \\
\hline & $(0.0019)$ & $(0.0187)$ & & & \\
\hline \multirow{2}{*}{ Trd Op } & $-0.0036^{* *}$ & 0.0235 & & & \\
\hline & $(0.0014)$ & $(0.0203)$ & & & \\
\hline
\end{tabular}

Note. The value in parentheses denotes the standard errors of corresponding estimates. ${ }^{* * *}, * *$ and $*$ indicate the significant level at $1 \%, 5 \%$ and $10 \%$ respectively.

Table 2 is divided into two parts; the first part is the results obtained at constant (level) condition, while the second part represents the results obtained with linear trend condition on the PMG estimations. The lag length selection is based on Aikake Information Criteria (AIC) while the numbers in the square brackets represent the optimal lag length selected when the maximum lag length is set at four. In this study, the AIC was preferred to the Schwarz Bayesian Criteria (SBC). This is because AIC tends to move from lowest possible lag order at a slow rate as the sample size increases, which may wander the chances of omission of relevant variables bias from the regression. Having said that, overestimation of the order of Auto Regressive (AR) seems preferable.

According to Pesaran et al. (1999), the decision to reject the null hypothesis of no causality can only be made when the Error Correction Term (ECT) is negative and significant. From the table, the ECT is indicated by the adjustment coefficients (Note 23). The estimations based on both conditions suggest that the existence of a long-run relationship between financial development and openness towards economic volatility cannot be rejected at significance levels with $5 \%$ and $10 \%$ respectively. However, since the ECT is only significant at 5\% and $10 \%$ significant level, further cointegration test is conducted to confirm for the existence of a stable long-run relationship among the variables as a robustness check. For the purpose, the Pedroni (1999) cointegration test is conducted. It is pointed out that the method estimate the pooled function through a "group mean" panel fully modified Ordinary Least Square (FMOLS) which not only generates consistent estimation in a small sample, but also is excellent in controlling for potential endogeneity in the right hand side of the model and serial correlation. Thus, the findings further contribute to the literature by addressing one of the most important questions of spurious correlation in the pooled estimations model. As the results suggest, the existence of a stable long-run relationship between financial development and openness towards economic volatility is further confirm at $1 \%$ significant level for the entire tests. This adds confidence to the PMG estimations that the existence of a long-run relationship among the variables cannot be rejected. The results are presented in Table 3.

Table 3. Pedroni cointegration test

\begin{tabular}{ccc}
\hline Test & Within-Dimension & Between-Dimension \\
\hline u- Statistic & $3.450 * * *$ & - \\
$\sigma$ - Statistic & $-4.086^{* * *}$ & $-3.356 * * *$ \\
PP- Statistic & $-13.572 * * *$ & $-14.587 * * *$ \\
ADF- Statistic & $-9.143 * * *$ & $-8.997 * * *$ \\
\hline
\end{tabular}

Note. ${ }^{* * *}$ indicate $1 \%$ significant level. The tests are conducted under deterministic trend and intercept trend assumption with AIC lag length selection criteria.

Thus, this indicates that the null hypothesis of no co-integration can be rejected and ascertains the existence of a significant consistent long-run relationship between economic volatility and financial development, together with openness in ASEAN-5 countries. The estimations also fit the actual graph very well. Hence, adding to confidence that the model may predict the effect of financial development and openness on economic volatility with highest precision. The actual fitted residual graph is presented by Figure 2 and 3 for references. 


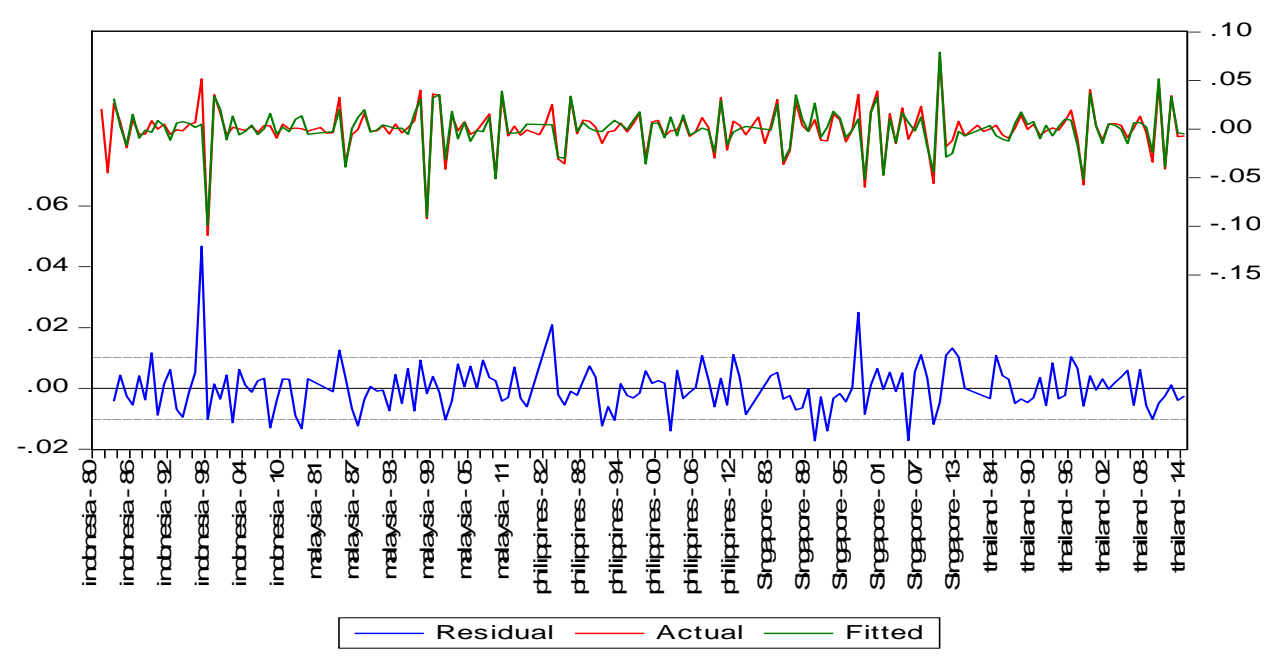

Figure 2. The actual fitted graph based on constant (level) settings

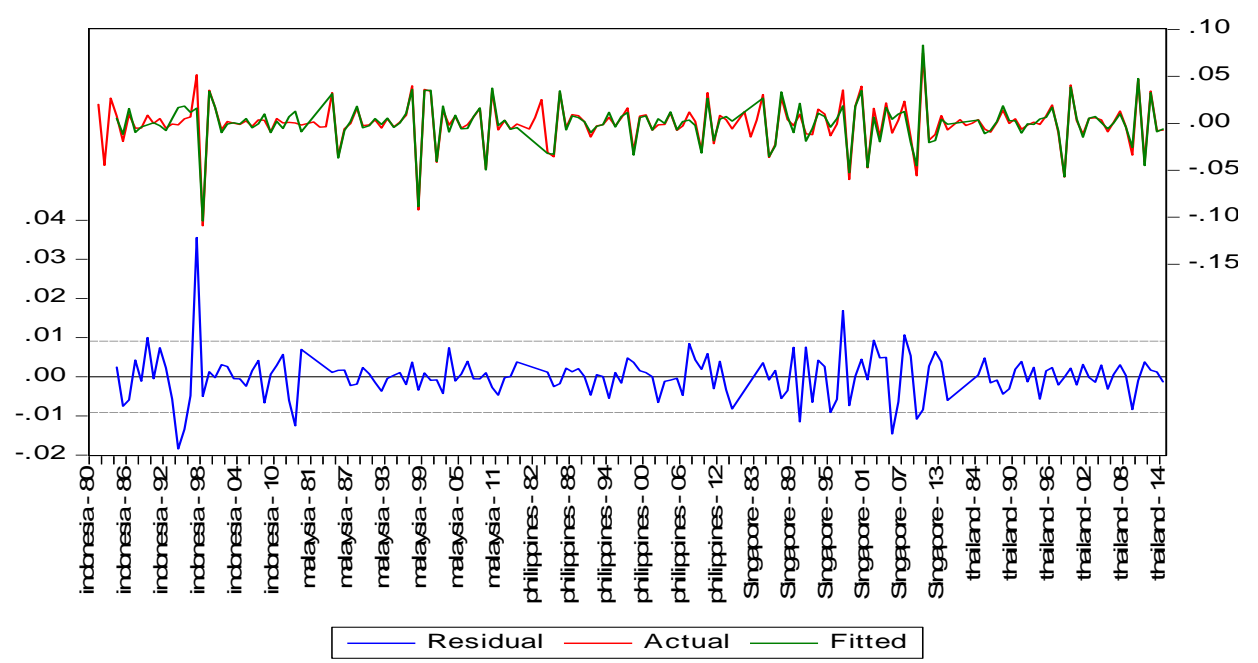

Figure 3. The actual fitted graph based on linear trend settings

From Table 2, the ECT also indicates that the variation in economic volatility is corrected by $1.71 \%$ when the first condition is applied and $2.33 \%$ when liner trend setting is in place over a year. In other words, when there is a shock on financial development and openness, the rate of economic volatility to restore to its equilibrium in the first year is as indicated by the adjustment rate (ECT). This means that the adjustment takes place relatively.

However, the questions remained was that financial development and openness may induce the likelihood of economic crises or they further instil economic stability. The answer to the questions is provided by the long-run and short-run coefficients in Table 2 (Note 24). As presented, the finding highlights that there is no evidence that higher financial and trade openness may further induce economic volatility in the long-run. It is a quite surprising result as one would expect that both financial and trade openness to significantly magnify economic volatility, which could trigger economic crises as hypothesised earlier. Instead, the result further suggests that both financial and trade openness may even have lower economic volatility in the long-run (Note 25). As indicated, an increase in financial openness may reduce economic volatility by $0.49 \%$ when the first condition is applied and $0.38 \%$ under the second condition. On the other hand, when there is a $1 \%$ increase in trade openness, economic volatility tends to reduce by $0.36 \%$ as suggested in the second condition, while there is no significant effect flowing from trade openness towards economic volatility in the first condition.

Therefore, this finding further challenges the earlier finding of Rodrik (1998), Stiglitz (2000), Blankenau et al. (2001), Razin et al. (2003), Kalemli Ozcan et al. (2003), Arora and Vamvakidis (2004), Schmukler (2004a; 2004b), Aghion et al. (2004) and Buch et al. (2005), for instance and adds to the existing literature that both 
financial and trade openness tend to reduce economic volatility and instil economic stability. This shows that financial openness may act as a medium of international risk sharing rather than the medium of contagion and increase investment portfolio diversification, while trade openness may further improve resource allocation, lower consumers' prices and lead to more efficient production, thus reducing volatility. This findings is parallel with such as Razin and Rose (1992), Beck et al. (2004), Chinn and Ito (2006), Bekaert et al. (2006) and Samsudin (2013) who also found the existence of smoothing effects flowing from financial and trade openness towards economic volatility in the long-run.

On the other hand, both segments of financial development also are found to significantly influence economic volatility in the long-run. From the results, an increase in the banking sector development tends to significantly smoothen economic volatility in the long-run by $1.02 \%$ when the model is in constant (level). Moreover, an increase in banking sector development reduces economic volatility by $3.16 \%$ in the long-run when linear trend condition is applied. In contrast, a $1 \%$ development in stock market sector could magnify economic volatility by $0.65 \%$ when the first condition is applied and $1.92 \%$ when the second condition is applied in the long-run as suggested. This shows that the banking sector development tends to reduce the chances of economic volatility, while the reverse is applied to the stock market sector development which is more likely to trigger economic crises in the long-run.

It is suggested that the nature of banking sector development may have a favourable impact on economic volatility in providing long-term financing and greater banker capabilities in detecting riskier investments. Besides, an increase in banking sector development may also increase its ability and efficiency to manage risk and detect more profitable investments. Hence, avoiding the chance of capital flight and stimulating investment in the economy may, in turn, preserve economic volatility. Other characteristics of banking sector development, such as improving capital structure, better resource allocation and facilitation of resource mobilisation, may lead to lowering economic volatility as these characteristics may preserve positive economic activity. This finding is also in line with Silva (2002) and Kose (2006) who found that banking sector development tends to reduce economic volatility. Particularly, Silva (2002) pointed out that the banking sector could reduce risk and volatility through its role in facilitating diversification and reducing asymmetric information. This effect, also known as the double welfare improvement effect, is useful for easing economic problems, especially in developing countries. In addition, Kose (2006) also added that a well-developed financial system could further reduce volatility by providing access to capital that may assist in diversifying the production base and hence reduce the effect of industrial specific shocks.

Stock market sector is more likely to be more susceptible towards large and sudden capital outflows, while its tendency to provide capital towards riskier investments also may worsen volatility in a longer term. It is also argued that as stock market sector gets more developed, it tend to offer more sophisticated financial instruments which are mostly risk indivisible. As pointed out by Acemoglu and Zilibotti (1997), the incapability to diversify risk may result in more volatility. Additionally, Mougani (2012) asserted that economic volatility is becoming more critical as portfolio investments tend to establish a short-term commitment. This may explain the positive nexus between stock market development and economic volatility in the long-run in this case. Furthermore, as pointed out by Singh (1997), a country which is at the intermediate level of stock market development is likely to make it a poor guide for effective investment, which may well applied to the ASEAN-5 phase of stock market development (Note 26). This also shows that the imperfections of capital market tend to magnify the effects of momentary productivity shocks and make them more persistent (Kiyotaki and Moore, 1997). Therefore, it is no surprise that in most occasions of economic crises, stock market sector tends to play an important part in worsening the situation.

In the short-run, it seems that the effect of both financial sector development and openness on economic volatility is not as obvious as in the long-run (Note 27). In terms of openness, the only variable which may significantly influence economic volatility is the financial openness in the first model (constant (level)). As suggested by the first model, financial openness tends to reduce economic volatility by $1.98 \%$ in the short-run. However, no significant effect is observed despite its smoothing effect in the second model. In terms of trade openness, even though there is a magnifying effect flowing of trade openness towards economic volatility in the short-run, the effect is not significant. This is also similar to the effect of banking sector development towards economic volatility in the short-run, where there is no significant effect observed despite its magnifying effect. This conclusion is applied in both conditions, constant and in linear trend. Except in the case of stock market sector development, it seems that economic volatility is significantly relaxed in the short-run. As suggested by the first condition, an increase in stock market sector development should reduce economic volatility by $2.69 \%$ and $4.69 \%$ when the second condition is applied (linear trend). 
The reducing effects flowing from stock market sector development towards economic volatility in the short-run can be explained by the benefit obtained from higher capital entry as it may reduce financial constraint faced by industries through access to external financing. With greater degree of financial openness, the amount of capital injected into the economy may further smoothen consumption shocks in the short-run which may mitigate excessive volatility. Interestingly as the result suggests, the effect of financial openness in controlling for economic volatility flowing from short-run to the long-run highlights the main role of financial openness in promoting greater international risk sharing. Except for stock market development in which the reducing effect does not flow from short-run to the long-run; greater stock market development may magnify economic volatility in a longer term due to vulnerability to capital turnaround.

In summary, greater openness and financial development may not lead to excessive economic volatility and are not likely to trigger economic crises in both long-and short-run. The only exception is in the case of stock market development in the long-run, where it may act as a medium of transmission of economic shocks. It has the potential to drag ASEAN-5 into another series of economic crises if it is not carried out properly. Therefore, promoting stock market sector development should be done with diligence and under strict regulation. Otherwise, the lesson learned from the 1997 East Asia financial crises may resurface and the current experience on the EU economic contagion may further extend its harmful volatility to ASEAN-5 region. The findings are robust to other tests such as Pedroni (1999) cointegration test and also fit the actual graph very well as presented in Table 3 and Figure 1 and 2. Therefore, these additional tests add to confidence on the result obtained.

\section{Conclusion}

In summary, the existence of a stable long-run relationship between financial development and openness towards economic volatility cannot be rejected. The findings are robust to other cointegration tests which add to confidence to the obtained results. In addition, the estimated coefficients also fit the actual graph very well which indicates that the measurement's error is at its minimum.

Cumulatively, there is no evidence that greater openness and financial development may drag ASEAN-5 into another series of economic crises in the long and short-run. The only exception is in the case of stock market sector development, where greater development on the sector is likely to trigger economic volatility in the long-run. This shows that the source of instability in ASEAN-5 is likely to be driven from greater stock market sector development. Therefore, deregulation and financial reform of the sector need to be carried out with diligence. Failure to do so may trigger economic volatility which may drag the region into another series of economic crises. Suffice to say, the re-current and rapid economic crises in recent decades have nothing to do with greater openness and banking sector development, but rather on stock market sector development in the case of ASEAN-5 countries. This also explains why the ASEAN countries has the least effects from the EU and US economic crises, as openness is more likely to be the medium of promoting stability through international risk sharing rather than the transmission of economic contagion.

Based on the findings, we can suggest that such effort by ASEAN under the Chiang Mai initiative, ASEAN Free Trade Area (AFTA), the ASEAN Comprehensive Investment Agreement (ACIA) and the ASEAN Economic Community (AEC) has proven to be fruitful to further liberalising their financial and trade sector as the economies tend to benefit from the experiences. Other inter-regional efforts such as under ASEAN +3 and Australian and New Zealand Free Trade Area (AANZFTA) should also be applauded as both act as an important engine in promoting greater economic stability. Therefore, further mutual agreement via inter and intra-regional economic arrangements in promoting greater openness in both finance and trade should be initiated and explored.

On the other hand, further banking sector formation may also benefit from these economies. This shows that the past financial formations are able to instil economic stability through greater capability in detecting riskier investments, work efficiency and long-term loan offering which is proven in stabilising the consumption shocks. It is suggested that if ASEAN could explore any possibilities of economic arrangements in promoting greater banking sector formation at regional or inter-regional level, it may further strengthen the smoothing effects flowing from banking sector development towards economic volatility. Nevertheless, the only exception and extra attention needed is in developing its stock market sector development. As the results suggest, stock market sector may be the medium of transmission for economic volatility which is in need of extra attention. If not carried out properly, it may drag ASEAN-5 into another series of economic crises in the long-run. Therefore, the ASEAN-5 effort in promoting the Asia Bond Market and the Asia Bond Fund initiative should be done with diligence. Further protective policy is recommended to be in place in order to protect the market from undesired external shocks which could trigger crises. Even though it seems a step back from promoting greater stock 
market sector development, it is essential in sustaining economic stability in the long-run. With this step, ASEAN-5 is unlikely to emulate the recent EU and US economic flux.

\section{Acknowledgments}

Many thanks to MPWS for providing editorial services to proofread the article and Craig Applegate at the University of Canberra for constructive comments and guides.

\section{References}

Acemoglu, D., \& Zilibotti, F. (1997). Was Prometheus unbound by chance? Risk, diversification, and growth. Journal of Political Economy, 105(4), 709-751.

Aghion, P., Bachetta, P., \& Banerjee, A. (2004). Capital markets and the instability of open economies. Journal of Monetary Economics, 51(6), 1077-1106.

Ahmed, A. D., \& Suardi, S. (2009). Macroeconomic Volatility, Trade and Financial Liberalization in Africa. World Development, 37(10), 1623-1636. http://dx.doi.org/10.1016/j.worlddev.2009.03.009

Ang, J. B., \& Mckibbin, W. J. (2007). Financial Liberalization, Financial Sector Development and Growth: Evidence from Malaysia Journal of Development Economics, 84(1), 215-233. http://dx.doi.org/10.1016/j. jdeveco.2006.11.006

Arestis, P., Demetriades, P. O., Fattouh, B., \& Mouratidis, K. (2002). The impact of financial liberalization policies on financial development: evidence from developing economies. International Journal of Finance and Economics, 7(2), 109-121.

Arora V. A. (2004). How Much Do Trading Partners Matter For Economic Growth? IMF Working Paper, 04/26, $1-20$.

Bank, A. D. (1997). Emerging Asia: Changes and Challenges. Manila: ADB.

Bank, W. (1993). The East Asian Miracle: Economic Growth and Public Policy. New York: Oxford University Press.

Baxter, M., \& King, R. (1999). Measuring business cycles: Approximate band-pass filters for economic time series. Review of Economic and Statistics, 81, 575-593.

Beck, T., \& Levine, R. (2002). Industry Growth And Capital Allocation: Does Having A Market- Or Bank-Based System Matter? Journal of Financial Economics, 64(2), 147-180.

Beck, T., \& Levine, R. (2004). Stock Markets, Banks, and Growth: Panel Evidence. Journal of Banking and Finance, 28(3), 423-442.

Beck, T., Demirgü̧̧-Kunt, A., \& Levine, R. (2000). A New Database on the Structure and Development of the Financial Sector. World Bank Economic Review, 14(3), 597-605.

Beck, T., Demirgüç-Kunt, A., \& Levine, R. (2004). Finance, inequality and poverty; Cross country evidence. National Bureau of Economic Research, 10979.

Bekaert, G., Harvey, C. R., \& Lundblad, C. (2006). Growth volatility and financial liberalization. Journal of International Money and Finance, 25(3), 370-403.

Blankenau, W., Kose, M. A., \& Yi, K. (2001). Can World Real Interest Rates Explain Business Cycles In A Small Open Economy? Journal of Economic Dynamics and Control, 25(6-7), 867-889.

Buch, C. M., Doepke, J., \& Pierdzioch, C. (2005). Financial openness and business cycle volatility. Journal of International Money and Finance, 24(5), 744-765.

Catao, L. A. V., \& Solomou, S. N. (2005). Effective exchange rates and the classical gold standard adjustment. American Economic Review, 95, 1259-1275.

Catao, L. A. V., \& Terrones, M. E. (2005). Fiscal deficits and inflation. Journal of Monetary Economics, 52, 529-554.

Chinn, M. D., \& Ito, H. (2006). What Matters For Financial Development? Capital Controls, Institutions, And Interactions. Journal of Development Economics, 81(1), 163-192. http://dx.doi.org/10.1016/j.jdeveco.2005. 05.010

Chinn, M. D., \& Ito, H. (2007a). Current Account Balances, Financial Development And Institutions: Assaying The World "Saving Glut". Journal of International Money and Finance, 26(4), 546-569. http://dx.doi.org/10.1016/j.jimonfin.2007.03.006 
Chinn, M. D., \& Ito, H. (2007b). A New Measure of Financial Openness. Journal of Comparative Policy Analysis, 10(3), 309-322.

Hnatkovska, V., \& Loayza, N. (2003). Volatility and Growth. World Bank Policy Research Working Paper, 3184, $1-40$.

Kalemli-Ozcan, S., Sorensen, B. E., \& Yosha, O. (2003). Risk sharing and industrial specialization: regional and international evidence. American Economic Review, 93(3), 903-918

Kao, C. (1999). Spurious regression and residual-based tests for cointegration in panel data. Journal of Econometrics, 90, 1-44.

Kim, D. H., Lin, S. C., \& Suen Y. B. (2009). Dynamic Effects of Trade Openness on Financial Development. Economic Modelling, 27(1), 254-261. http://dx.doi.org/10.1016/j.econmod.2009.09.005

Kiyotaki, N., \& Moore, J. (1997). Credit Cycles. Journal of Political Economy, 105(2), 211- 248.

Kose, M. A., Prasad, E. S., \& Terrones, M. E. (2006). How do trade and financial integration affect the relationship between growth and volatility? Journal of International Economics, 69(1), 176-202. http://dx.doi.org/10.1016/j.jinteco.2005.05.009

Lane, P. R., \& Milesi-Ferretti, G. M. (2006). The external wealth of nations Mark II: revised and extended estimates of foreign assets and liabilities, 1970-2004. Journal of International Economics, 73(2), 223-250.

McKinnon, R. I. (1973). Money and Capital in Economic Development Massachusetts Avenue, Washington D.C.: Brookings Institution Press.

Mougani, G. (2012). An Analysis of the Impact of Financial Integration on Economic Activity and Macroeconomic Volatility in Africa within the Financial Globalization Context. African Development Bank Working Paper, 144, 1-34.

Neyapti, B. (2001). Central bank independence and economic performance in Eastern Europe. Economic Systems, 25(4), 381-399.

Pedroni, P. (1999). Critical values for cointegration tests in heterogeneous panels with multiple regressors. Oxford Bulletin of Economics and Statistics, 61, 653-670.

Pesaran, M. H., Shin, Y., \& Smith, R. J. (1999). Pooled Mean Group estimation and dynamic heterogeneous panels. Journal of the American Statistical Association, 94, 621-634.

Pindyck, R. S. (1991). Irreversibility, uncertainty, and investment. Journal of Economic Literature, 29(3), 1110-1148.

Razin, A., \& Rose, A. K. (1992). Business-cycle volatility and openness-An exploratory cross-sectional analysis. In Capital mobility: The impact on consumption, investment, and growth (pp. 48-76). Cambridge: Cambridge University Press.

Razin, A., Sadka, E., \& Coury, T. (2003). Trade openness, investment instability and terms-of-trade volatility. Journal of International Economics, 61(2), 285-306.

Rodrik, D. (1998). Who Needs Capital-Account Convertibility? In S. Fischer, R. N. Cooper, R. Dornbusch, P. M. Garber, C. Massad, J. J. Polak, D. Rodrik, \& S. S. Tarapore (Eds.), Should The IMF Pursue Capital-Account Convertibility? (pp. 55-65). Department Of Economics, Princeton University, Princeton, NJ.

Samsudin, H. (2013). Economic volatility: Does financial development, openness and institutional quality matter in case of ASEAN-5 countries. The 42nd Australian Conference of Economists proceedings, 42, 1-12.

Schmukler, S. (2004a). Benefits and Risks of Financial Globalization: Challenges for Developing Countries. World Bank Development Research Group, 84962, 1-29.

Schmukler, S. (2004b). Financial globalization: gains and pain for developing countries (E. Review Ed.). Washington, DC: Federal Reserve Bank of Atlanta.

Shaw, E. S. (1973). Financial deepening in economic development. Oxford: Oxford University Press.

Silva, G. F. (2002). The impact of financial system development on business cycles volatility: cross-country evidence. Journal of Macroeconomics, 24(2), 233-253.

Stiglitz, J. (2000). Capital market liberalization, economic growth, and instability. World Development, 28(6), 1075-1086. 


\section{Notes}

Note 1. The ASEAN-5 refers to Indonesia, Malaysia, The Philippines, Singapore and Thailand.

Note 2. These five economies are the original setup of ASEAN and remained as the main players in ASEAN with a consistent combined GDP of more than $80 \%$ of all ASEAN countries. This justify why these five economies were in the centre of focus rather than the whole region. Although a study of all the member countries of ASEAN would be more comprehensive, the data gathering process is not an easy task for countries such as Myanmar, Brunei, Laos, Cambodia and Vietnam.

Note 3. If ASEAN-5 is count as a single market, they rank after China especially in electrical and manufacturing products.

Note 4. In this study openness is divided into two perspectives, which is trade and financial openness.

Note 5. Financial development is defined as an aspect of economics that concerns the growth of the financial sector, focusing on finance and investment management, and which involves banking institutions and stock markets, respectively.

Note 6. As stressed earlier, economic volatility has become more severe in the event of crises. Therefore, the discussions in this section will focus on the literature related to business cycle and economic volatility.

Note 7. The finding is based on the dynamic effects of trade openness and financial development by utilizing Pooled Mean Group (PMG) estimations on 88 countries for the period of 1960 to 2005.

Note 8. Essentially, when the data had taken the form of a logarithm, the entire data will have a similar unit of measurements as well as reducing widely varying quantities to much smaller ranges.

Note 9. Turning the data into logarithm form may reduce the chances of the variables to exhibit an exponential or polynomial trend, hence increasing the likelihood of the model to be correctly specified as linear.

Note 10. According to Catao and Solomou (2005) and Catao and Terrones (2005), endogeneity can be further reduced in a dynamic panel model and also deals with the substantial persistence of financial development and openness adjustments and depicts the potentially rich economic volatility adjustments dynamics.

Note 11. As pointed out by Kao (1999), the estimated structural parameter tying two independent non-stationarity variables tend to converge to zero in the case of panel data analysis, while it is a random variable in the case of time series. In other words, the point estimations of the parameters value will still be consistent. However, the non-stationarity panel data may lead to biased standard errors. Since the PMG estimator is able to take both $I(1)$ and $I(0)$ stationarity variables in the same model, there will be less issue with biased standard errors. Hence, it highlights the advantages of PMG estimator.

Note 12. The data are regularly updated and can be obtained directly from the author or through http://www.philiplane.org/EWN.html.

Note 13. This study utilized annually data.

Note 14. BP filter tend to eliminate unit roots and de-trending the time series stationary. It also does not suffer from variables timing relationship bias as in first differencing method and it detach business cycle frequencies without re-weighting components as well as establish the most optimal estimation of ideal band-pass filter through moving average with infinite order. Finally, through BP filtering method, the business cycles components generated are independent from the length of the sample period.

Note 15. Please refer to footnote 5 for the definition of financial development.

Note 16. The questions about which segments of financial system development may significantly smoothen or magnify economic volatility have been without any merit, particularly with regards to ASEAN-5 countries.

Note 17. Domestic credits to private sector indicator can be referred to as a financial resource made available to the private sector through loans, purchases of non-equity securities, trade credits, and other receivable accounts which establish a claim for repayment. This measurement excludes credit granted to the public sector and credit issued by the central bank. It is recognized that the private sector is more efficient in utilizing available funds, thus reflecting efficient resource allocation. This indicator reflects an overall development in the banking sector as well as financial depth.

Note 18. The other two indicators reflect the activeness of stock market which comprises of profit taking foreign investors and foreign fund in the financial system, which may be an insufficient measure of financial development. 
Note 19. The de facto indicator might reflect the country's history of financial openness as it depicts the overall accumulation of assets and liabilities.

Note 20. If, let say, a country has lifted barriers to more liberalise condition, this does not imply greater capital account openness if the right to engage in international transaction is not fully utilized; then the de jure would overstate the actual level of capital openness.

Note 21. There are some concerns with the de jure financial openness measurements because the data for Thailand exhibited no variation from 1970 to 2007, which signifies inconsistencies with the financial openness experienced. It is well known that the Thai government has taken an important step in reducing FDI restrictions and financial barriers as well as liberalising foreign borrowings, especially between the late 1980s and the mid-90s. In the post 1997 crisis era, the reverse may apply hence reflect some variation in financial openness which is contradicted by the data.

Note 22. The de jure measurement of financial openness was constructed by Chinn and Ito (2007b) who derived the index of capital account openness (KAOPEN) from four binary dummy variables which reflect the cross border financial transactions restrictions reported in the IMF's Annual Report on Exchange Arrangements and Exchange Restrictions (AREAER). There are some doubts with this, as the dummy variables are produced by utilizing the principal components analysis and may suffer from measurement error because some variation of the underlying data may not be documented.

Note 23. The ECT also indicate the speed of adjustment which restores the equilibrium from short-run to long-run following a shocks in the dynamic model. Therefore, the ECT is also referred as the adjustment coefficient.

Note 24. Since the PMG approach may allow for the error variances to vary across countries in the short-run, the short-run causality coefficients for each country can be estimated. However, it will be made available upon request.

Note 25. The only exception is when the first condition is applied (constant (level)) where the smoothing effect of trade openness on economic volatility in the long-run is not significant. However, in the second model (linear trend), trade openness significantly reduced economic volatility at 5\% significant level.

Note 26. Even though it is argued that Singapore may have reached the level of developed economy, in term of financial sector development Singapore are still considered as an emerging economy. These are reported in several publications and the following links might clarify the arguments. http://www.economist.com/node/2350141, http://business.nab.com.au/east-asian-emerging-market-economies-june-2014-6919/, http://www.nasdaq.com/article/emerging-markets-singapore-remarkable-50-years-cm496488.

Note 27. The short-run causality presented in Table 2 is the aggregate estimations based on ASEAN- 5 countries. The individual short-run causality at each country level is also available. Nevertheless, for simplicity the short-run causality at each country level is not discussed and only made available upon request.

\section{Copyrights}

Copyright for this article is retained by the author(s), with first publication rights granted to the journal.

This is an open-access article distributed under the terms and conditions of the Creative Commons Attribution license (http://creativecommons.org/licenses/by/3.0/) 